\title{
STUDIES OF RESPIRATORY PHYSIOLOGY IN THE NEWBORN INFANT. I. OBSERVATIONS ON NORMAL PREMATURE AND FULL-TERM INFANTS ${ }^{1}$
}

\author{
By CHARLES D. COOK, RUTH B. CHERRY, DONOUGH O'BRIEN, ${ }^{2}$ PETTER \\ KARLBERG, ${ }^{3}$ AND CLEMENT A. SMITH \\ (From the Boston Lying-in Hospital and the Department of Pediatrics, Harvard Medical School, \\ Boston, Mass.)
}

(Submitted for publication January 3, 1955 ; accepted February 2, 1955)

This report describes an investigation of the respiratory physiology of normal premature and full-term newborn infants. As in previous studies on normals (1-3), minute volumes, rates and tidal volumes have been measured. Additional measurements of $\mathrm{CO}_{2}$ production, plasma $\mathrm{CO}_{2}$ partial pressure, and intraesophageal pressure differences have allowed calculations of effective alveolar ventilation, functional dead space and estimates of the work of respiration. Since certain adaptations were necessary for the study of this age group, the techniques are reported in detail. The data from normal infants are the subject of this report; comparable data for newborns with respiratory distress are reported in a second paper (4).

\section{MATERIAL}

The 63 infants studied by one or more techniques were delivered at the Boston Lying-in Hospital and were considered normal in all respects except that 17 were premature by weight. They ranged from 36 to 42 weeks gestational age and from 1.82 to $4.25 \mathrm{Kg}$. birth weight. Delivery was spontaneous vertex or low forceps except in five infants delivered by Caesarian section (three because of previous section, one for marginal placental separation, and one for postmaturity), and four by breech extraction. Their ages at the time of observation ranged from three hours to seven days (Tables I-III). Most of those under two days had not been fed prior to the studies.

\section{METHODS}

The minute volume $(V), 4$ rate (f), and tidal volume $\left(V_{T}\right)$, were measured in 35 infants by means of a 65 -liter

1 One of a series of studies supported by a research grant from the Association for the Aid of Crippled Children, New York City.

2 Work done under Grocers' Company Research Scholarship, and Research Fellowship from the Lederle Company; Present Address: Department of Child Health, Guy's Hospital, London.

3 Work done under Rockefeller Fellowship; Present Address: Karolinska Sjukhuset, Stockholm.

4 Throughout this paper the symbols employed to denote respiratory variables are those suggested for pur- body plethysmograph in which the infant lay on its back, with the face emerging through a pneumatic ring (Figure 1). The apparatus, which was similar to that described by Cross (2), was largely assembled by Dr. Frank Hytten. Most of these infants, none of whom were sedated, were sufficiently comfortable to sleep throughout the observations. Only data on infants who were considered to be resting and basal are included in this report. An average of seven minutes of quiet breathing was used in calculating the results.

The body plethysmograph was connected to a Krogh spirometer, and the entire system was checked for leaks with a $6 \mathrm{gm}$. weight placed on the spirometer float; maintenance of air in the spirometer for more than twenty seconds indicated an error of less than 2 per cent in minute volume recording and was considered satisfactory. Kymograph tracings of respiratory pattern were obtained from a writing pen attached to the spirometer float, and minute volume from an automatic integrator as designed by Roberts and Widdas (6). This recorder utilized a photoelectric cell and integrator to count flickers of light produced by the spirometer moving one of a pair of transilluminated grids. The entire plethysmograph-spirometer-integrator system was calibrated at least once with each study with a syringe and pump which produced rhythmical volume changes of a known amount. The calibration per ml. was constant with pump rates varying between 30 and 60 per minute. With higher rates, however, there was a progressive systematic overswing of the spirometer so that integrator counts increased per $\mathrm{ml}$. When studying infants with elevated respiratory rates (only those with respiratory difficulty) a factor was applied to correct for this systematic error. At rates of 80 the correction amounted to 6 per cent and at 100 to 15 per cent.

The $\mathrm{CO}_{2}$ production $\left(\mathrm{V}_{\mathrm{CO}_{2}}\right)$ and $\mathrm{O}_{2}$ consumption $\left(\nabla_{\mathrm{O}_{2}}\right)$ of 16 infants were determined by using a plastic face mask with a volume of approximately $60 \mathrm{ml}$. sealed to the pneumatic ring (Figure 1) with an aquaresin-glycerine mixture. ${ }^{5}$ Compressed air or other oxygen-nitrogen mixtures were drawn by a pump across the infant's face

poses of standardization by a group of clinical and research respiratory physiologists headed by J. R. Pappenheimer (5).

5 Aquaresin, obtained from the Glyco Products Co., Brooklyn, N. Y., was mixed with equal parts glycerine. This provided an effective seal without injuring the rubber cuff. 
TABLE I

Minute volume, respiratory rate and tidal volume of 35 normal infants *

(All volumes are BTPS)

\begin{tabular}{|c|c|c|c|c|c|c|c|c|}
\hline $\begin{array}{c}\text { Infant } \\
\text { No. }\end{array}$ & $\begin{array}{c}\text { Birth } \\
\text { weight } \\
K g .\end{array}$ & Age & $\begin{array}{c}\text { Weight } † \\
K g .\end{array}$ & $\begin{array}{c}\text { Inspired } \\
\text { gas }\end{array}$ & Min. 8 & $\dot{\mathrm{V}}$ & $\mathbf{f}$ & $\begin{array}{l}\mathrm{VT}_{\mathrm{T}} \\
m l .\end{array}$ \\
\hline 6 & 2.41 & $3 \mathrm{~d}$. & 2.42 & R.A. & 8.0 & 454 & 27 & 17 \\
\hline 7 & 2.71 & $6 \mathrm{hr}$. & - & R.A. & 6.5 & 473 & 36 & 13 \\
\hline 10 & 4.08 & $7 \mathrm{hr}$. & 一 & R.A. & 8.0 & 770 & 37 & 21 \\
\hline 11 & 2.51 & $6 \mathrm{hr}$ & - & R.A. & 11.0 & 330 & 30 & 11 \\
\hline 12 & 2.67 & 30 hr. & 2.68 & R.A. & 4.0 & 552 & 34 & 16 \\
\hline 13 & 2.33 & $5 \mathrm{hr}$. & 2.31 & R.A. & 33.0 & 520 & 34 & 15 \\
\hline 14 & 2.75 & 5 hr. & - & R.A. & 7.0 & 515 & 27 & 19 \\
\hline 17 & 2.06 & $2 \mathrm{~d}$ & 1.88 & R.A. & 7.0 & 290 & 46 & 6 \\
\hline 25 & 3.06 & $11 \mathrm{hr}$. & - & R.A. & 8.0 & 485 & 27 & 18 \\
\hline 26 & 2.62 & $12 \mathrm{hr}$. & - & R.A. & 4.5 & 584 & 46 & 13 \\
\hline 30 & 2.41 & $4 \mathrm{~d}$ & 2.38 & R.A. & 9.5 & 405 & 31 & 13 \\
\hline 32 & 3.16 & $12 \mathrm{hr}$. & 2.86 & R.A. & 3.0 & 569 & 33 & 17 \\
\hline 37 & 3.02 & $29 \mathrm{hr}$ & 2.85 & C.A. & 5.0 & 458 & 31 & 15 \\
\hline 38 & 2.50 & $4 \mathrm{~d}$ & 2.28 & R.A. & 3.0 & 420 & 32 & 13 \\
\hline 45 & 2.60 & $24 \mathrm{hr}$. & 2.42 & R.A. & 2.5 & 463 & 40 & 12 \\
\hline 48 & 2.33 & $12 \mathrm{hr}$. & 2.25 & C.A. & 2.0 & 538 & 35 & 15 \\
\hline 51 & 2.98 & 5 hr. & 2.85 & C.A. & 5.5 & 486 & 38 & 13 \\
\hline 56 & 3.31 & $7 \mathrm{~d}$ & 3.06 & C.A. & 6.0 & 840 & 40 & 21 \\
\hline 57 & 3.23 & $3 \mathrm{~d}$. & 2.93 & C.A. & 3.5 & 564 & 28 & 20 \\
\hline 58 & 2.55 & $10 \mathrm{hr}$ & 2.50 & C.A. & 3.0 & 402 & 33 & 12 \\
\hline 60 & 2.88 & $20 \mathrm{hr}$. & 2.90 & C.A. & 8.5 & 746 & 51 & 15 \\
\hline 61 & 2.50 & $13 \mathrm{hr}$ & 2.49 & C.A. & 2.0 & 845 & 49 & 17 \\
\hline 62 & 2.36 & $16 \mathrm{hr}$. & 2.29 & C.A. & 4.5 & 421 & 23 & 18 \\
\hline 63 & 2.72 & $21 \mathrm{hr}$ & 2.65 & C.A. & 7.5 & 466 & 32 & 15 \\
\hline 65 & 3.04 & $25 \mathrm{hr}$. & 2.82 & C.A. & 2.5 & 550 & 28 & 20 \\
\hline 66 & 3.92 & $16 \mathrm{hr}$. & 3.75 & C.A. & 7.0 & 579 & 30 & 19 \\
\hline 68 & 3.72 & $17 \mathrm{hr}$. & 3.61 & C.A. & 4.0 & 579 & 28 & 21 \\
\hline 69 & 1.82 & $21 \mathrm{hr}$ & 1.76 & C.A. & 2.0 & 383 & 26 & 15 \\
\hline 71 & 3.52 & $21 \mathrm{hr}$ & 3.32 & C.A. & 17.0 & 481 & 29 & 17 \\
\hline 76 & 2.64 & $11 \mathrm{hr}$. & 2.63 & C.A. & 10.0 & 600 & 29 & 21 \\
\hline 80 & 2.46 & $15 \mathrm{hr}$. & 2.35 & C.A. & 4.0 & 435 & 31 & 14 \\
\hline 81 & 2.81 & $12 \mathrm{hr}$ & 2.58 & C.A. & 8.5 & 453 & 33 & 14 \\
\hline 83 & 3.26 & $23 \mathrm{hr}$. & 3.09 & C.A. & 13.5 & 564 & 40 & 14 \\
\hline 84 & 1.94 & $16 \mathrm{hr}$ & - & C.A. & 5.0 & 480 & 37 & 13 \\
\hline 86 & 2.28 & $2 \mathrm{~d}$ & 2.04 & C.A. & 6.0 & 444 & 32 & 14 \\
\hline
\end{tabular}

* BTPS-Body temperature, pressure, saturated with water vapor.

$\dot{\mathrm{V}}$-minute volume.

f-respiratory rate per minute.

$\mathrm{V}_{\mathbf{T}}$-tidal volume.

† Seven infants studied during the first 24 hours after birth were not weighed at time of study; their birth weights are used in Figure 2.

$\ddagger$ R.A. = room air.

C.A. = compressed air.

$\S$ Number of resting minutes averaged.

at the rate of 5 to 6 liters per minute and delivered, together with the expired air, into plastic collecting bags. At this rate, analyses of mask air never showed more than 0.3 volumes per cent $\mathrm{CO}_{2}$. A small series of studies on the same infants breathing room air and then compressed air, and a comparison of the group of infants studied in room air with the group studied in compressed air showed no statistically significant difference in minute volume $(P=0.95)$. Thus it seems probable that respiration was not appreciably influenced by the use of the mask. Gas collection periods used for calculations averaged 3.5 minutes; the volume collected was measured with a dry gas meter which had an error of 1.5 per cent or less.
Analyses for $\mathrm{CO}_{2}$ and $\mathrm{O}_{2}$ in the inspired gas and in that from the collecting bags were performed in the Scholander $0.5 \mathrm{ml}$. gas analyzer (7). Analyses of $\mathrm{CO}_{2}$ were made at least in duplicate in every case, with a standard deviation from the averages of these duplicate determinations of \pm 0.007 volumes per cent for the inspired air, and \pm 0.013 volumes per cent for the diluted expired air. This degree of reproducibility amounted to a variation of approximately \pm 5 per cent of the total $\mathrm{CO}_{2}$ production per minute. Oxygen analyses, also performed at least in duplicate, showed a standard deviation from the averages of \pm 0.012 volumes per cent for both inspired and expired air. The Scholander analyzer was checked against a Haldane apparatus with resultant 
TABLE II

Additional physiologic observations in 18 normal infants * (All volumes are BTPS)

\begin{tabular}{|c|c|c|c|c|c|c|c|c|c|c|c|c|c|c|}
\hline $\begin{array}{c}\text { Infant } \\
\text { No. }\end{array}$ & $\begin{array}{c}\text { Birth } \\
\text { weight } \\
K \boldsymbol{K} .\end{array}$ & Age & $\underset{m l}{\dot{\mathrm{V}}}$ & f & $\begin{array}{l}\mathrm{VT} \\
\mathrm{ml} .\end{array}$ & $\begin{array}{c}\dot{\mathrm{V}} \mathrm{CO}_{2} \\
m l .\end{array}$ & $\begin{array}{l}\dot{V}_{o_{2}} \\
m l .\end{array}$ & $\mathbf{R}$ & $\begin{array}{l}\mathrm{Ca}_{\mathrm{CO}_{2}} \\
\text { vol. } \%\end{array}$ & $\mathrm{pH}$ & $\begin{array}{c}\mathrm{Pa}_{\mathrm{CO}} \\
m m . H g\end{array}$ & $\underset{m \hat{l} .}{\dot{\mathrm{V}}_{\hat{\mathrm{A}}}}$ & $\begin{array}{c}\text { VD } \\
m l .\end{array}$ & $\mathbf{V}_{\mathbf{D}} / \mathbf{V}_{\mathbf{T}}$ \\
\hline 48 & 2.33 & $12 \mathrm{hr}$. & 600 & $\begin{array}{l}36 \\
30\end{array}$ & 17 & 17.5 & 21.6 & $\begin{array}{r}.81 \\
73\end{array}$ & - & - & - & - & - & - \\
\hline $\begin{array}{l}51 \\
56\end{array}$ & $\begin{array}{l}2.98 \\
3.31\end{array}$ & $\begin{array}{l}5 \mathrm{hr} . \\
7 \mathrm{~d} .\end{array}$ & $\begin{array}{l}498 \\
825\end{array}$ & $\begin{array}{l}39 \\
39\end{array}$ & $\begin{array}{l}13 \\
21\end{array}$ & $\begin{array}{l}15.5 \\
25.9\end{array}$ & $\begin{array}{l}21.2 \\
36.0\end{array}$ & $\begin{array}{l}.73 \\
.72\end{array}$ & $\overline{47}$ & $\overline{7.40}$ & $\overline{32}$ & $\overline{581}$ & $\overline{6.3}$ & $\overline{30}$ \\
\hline 58 & 2.55 & $10 \mathrm{hr}$. & 418 & 33 & 13 & 12.9 & 19.8 & $.6 \overline{5}$ & 51 & 7.37 & 37 & 241 & 5.4 & .42 \\
\hline 60 & 2.88 & $20 \mathrm{hr}$. & 751 & 52 & 14 & 16.0 & 22.8 & .70 & 43 & 7.35 & 33 & 351 & 7.7 & .55 \\
\hline 61 & 2.50 & $13 \mathrm{hr}$. & 835 & 50 & 17 & 16.4 & 20.2 & .81 & 39 & 7.41 & 26 & 452 & 7.7 & .45 \\
\hline 62 & 2.36 & $16 \mathrm{hr}$. & 465 & 24 & 19 & 14.4 & 24.4 & .59 & 44 & 7.42 & 29 & 354 & 4.6 & .24 \\
\hline 63 & 2.72 & $21 \mathrm{hr}$. & 486 & 34 & 14 & 12.6 & 20.3 & .62 & 49 & 7.40 & 34 & 272 & 6.3 & .45 \\
\hline 65 & 3.04 & $25 \mathrm{hr}$. & 562 & 29 & 19 & 16.4 & 19.9 & .82 & 54 & 7.43 & 35 & 344 & 7.5 & .39 \\
\hline 66 & 3.92 & $16 \mathrm{hr}$. & 578 & 29 & 20 & 18.2 & 25.5 & .71 & 57 & 7.45 & 35 & 370 & 7.2 & .36 \\
\hline 68 & 3.72 & $17 \mathrm{hr}$. & 590 & 28 & 21 & 19.5 & 28.1 & .69 & 49 & 7.43 & 31 & 446 & 5.1 & .24 \\
\hline 69 & 1.82 & $21 \mathrm{hr}$. & 383 & 26 & 15 & 10.5 & 22.0 & .48 & 46 & 7.51 & 25 & 302 & 3.1 & .21 \\
\hline 71 & 3.52 & $21 \mathrm{hr}$. & 463 & 28 & 17 & 15.0 & 21.0 & .71 & 49 & 7.50 & 27 & 398 & 2.3 & .14 \\
\hline 76 & 2.64 & $11 \mathrm{hr}$. & 676 & 31 & 22 & 22.2 & 24.7 & .90 & 54 & 7.46 & 32 & 492 & 5.9 & .27 \\
\hline 80 & 2.46 & $15 \mathrm{hr}$. & 435 & 31 & 14 & 13.3 & 18.4 & .72 & 53 & 7.35 & 40 & 234 & 6.5 & .46 \\
\hline 83 & 3.26 & $23 \mathrm{hr}$. & 543 & 39 & 14 & 17.5 & 22.2 & .79 & 51 & 7.47 & 30 & 410 & 3.4 & .24 \\
\hline 84 & 1.94 & $16 \mathrm{hr}$. & 480 & 37 & 13 & 14.7 & 17.4 & .84 & 42 & 7.45 & 26 & 418 & 1.7 & .13 \\
\hline 86 & 2.28 & $2 \mathrm{~d}$. & 444 & 32 & 14 & 11.5 & 14.8 & .78 & 51 & 7.52 & 27 & 307 & 4.3 & .31 \\
\hline
\end{tabular}

* $\dot{\mathrm{V}}_{\mathrm{CO}_{2}}-\mathrm{CO}_{2}$ production per minute. $\dot{\mathrm{V}}_{\mathrm{O}_{2}}-\mathrm{O}_{2}$ consumption per minute. $\mathrm{R}$-respiratory exchange ratio.
$\mathrm{CaCO}_{2}-\mathrm{CO}_{2}$ concentration in plasma.

$\mathrm{PaCO}_{2}-\mathrm{CO}_{2}$ pressure in plasma.

$\dot{\mathrm{V}}_{\mathrm{A}}$-alveolar ventilation per minute.

$V_{D}$-functional dead space.

All infants were breathing compressed air; the $\dot{V}, f$, and $V_{T}$ values differ from those given in Table $I$ for the same infants, as they were obtained during observation periods necessarily shortened for measurement of $\mathrm{CO}_{2}$ production and $\mathrm{O}_{2}$ consumption.

agreement within 3 per cent of the $\dot{\mathrm{V}}_{\mathrm{CO}_{2}}$ measured and 6 per cent of the $\mathrm{V}_{\mathrm{O}_{2}}$.

"Arterialized" capillary blood for $\mathrm{pH}$ and $\mathrm{CO}_{2}$ analyses was obtained by heating the foot for ten minutes in 45 to $47^{\circ} \mathrm{C}$. water, puncturing the heel, and drawing the freely flowing blood into a funnel-syringe combination with heparin ${ }^{6}$ and mineral oil filling the dead space and mercury present for mixing (8). The effect of this brief air exposure upon blood $\mathrm{pH}$ and $\mathrm{CO}_{2}$ was repeatedly demonstrated to be less than the small error of the analysis. Moreover, the $\mathrm{pH}$ and $\mathrm{CO}_{2}$ values obtained were similar to those reported by Graham and his co-workers for temporal artery blood of normal infants (9). The blood samples were taken immediately after the period of gas collection and without changing the inspired gas mixture. Although the infants often cried briefly when the heel was punctured, a comparison between analyses on the first few drops of blood and later drops showed no significant change: In several infants, repeated blood samples obtained two to three times during periods up to two hours showed no significant change in $\mathrm{pH}$ and $\mathrm{CO}_{2}$ concentration $\left(\mathrm{Caco}_{2}\right)$; therefore the post-observation blood value was assumed to be representative of the entire collection period.

Plasma $\mathrm{pH}$, as determined in duplicate or triplicate with a Beckman glass micro-electrode adapted to a Cambridge $\mathrm{pH}$ meter (10) and reproducible within \pm 0.01

6 The liquid heparin diluted the blood sample 0.4 per cent or less.
$\mathrm{pH}$ units, was corrected for temperature as suggested by Rosenthal (11). Plasma $\mathrm{CO}_{2}$ content was directly determined in duplicate by the micro-Scholander syringe technique (12) with a standard deviation of \pm 0.9 volumes per cent.

Intraesophageal pressure changes, which have been shown to be an index of intrapleural pressure differences (13), were measured as described by McIlroy, Marshall, and Christie (14) and Mead, McIlroy, Selverstone, and Kriete (15) during the quiet respiration of 28 infants. A $1 \mathrm{~mm}$. internal diameter polyethylene catheter with multiple openings near the distal end was filled with water, attached to an electric manometer-amplifier-recording ${ }^{7}$ system, and passed approximately $10 \mathrm{~cm}$. through the nose or mouth. The system was calibrated with a water manometer after each study. The differences between maximal and minimal pressures occurring with each respiratory cycle during periods of quiet breathing were averaged for at least 15 individual breaths.

\section{CALCULATIONS}

The Henderson-Hasselbalch equation (16) was used for calculation of arterial $\mathrm{P}_{\mathrm{CO}_{2}}\left(\mathrm{PaCO}_{2}\right)$ from plasma $\mathrm{pH}$ and $\mathrm{CO}_{2}$ concentration. The relative constancy of $\mathrm{PaCO}_{2}$ in blood drawn several times during a period of one to two

7 The electric manometer, amplifier and recorder were made by the Sanborn Company, Cambridge, Massachusetts. 
TABLE III

Intraesophageal pressure differences in 25 normal newborn infants

\begin{tabular}{|c|c|c|c|c|c|}
\hline \multirow{2}{*}{$\begin{array}{c}\text { Infant } \\
\text { No. }\end{array}$} & \multirow{2}{*}{$\begin{array}{c}\text { Birth } \\
\text { weight } \\
\boldsymbol{K} \boldsymbol{g} .\end{array}$} & \multirow[b]{2}{*}{ Age } & \multicolumn{3}{|c|}{$\begin{array}{c}\Delta \mathrm{IEP} \\
\mathrm{cm} \cdot \mathrm{H}_{2} \mathrm{O}\end{array}$} \\
\hline & & & Min. & Max. & Mean \\
\hline $\mathrm{P}-1$ & 2.36 & $20 \mathrm{hr}$. & 3.9 & 5.6 & 4.9 \\
\hline $\mathrm{P}-4$ & 3.06 & $8 \mathrm{hr}$. & 3.7 & 7.2 & 5.1 \\
\hline$P-5$ & 4.25 & $7 \mathrm{hr}$. & 2.4 & 3.0 & 2.7 \\
\hline $\mathrm{P}-7$ & 2.30 & $2 \mathrm{~d}$. & 1.8 & 4.3 & 3.5 \\
\hline $\mathrm{P}-9$ & 3.36 & $13 \mathrm{hr}$. & 2.9 & 7.3 & 5.1 \\
\hline$P-12$ & 3.30 & $23 \mathrm{hr}$. & 1.2 & 7.3 & 3.7 \\
\hline$P-14$ & 3.08 & $2 \mathrm{~d}$. & 2.0 & 6.0 & 3.9 \\
\hline$P-17$ & 1.86 & $33 \mathrm{hr}$. & 2.6 & 8.1 & 4.7 \\
\hline $\mathrm{P}-20$ & 2.92 & $3 \mathrm{hr}$. & 1.7 & 5.8 & 3.6 \\
\hline$P-26$ & 2.82 & $34 \mathrm{hr}$. & 3.2 & 10.7 & 5.9 \\
\hline$P-27$ & 2.99 & $34 \mathrm{hr}$. & 3.5 & 10.2 & 6.6 \\
\hline $\mathrm{P}-30$ & 3.66 & $6 \mathrm{~d}$ & 10.9 & 14.9 & 12.6 \\
\hline$P-32$ & 2.78 & $9 \mathrm{hr}$. & 2.9 & 7.3 & 4.4 \\
\hline $\mathrm{P}-33$ & 3.06 & $11 \mathrm{hr}$. & 4.8 & 7.5 & 6.0 \\
\hline $\mathrm{P}-34$ & 2.38 & $15 \mathrm{hr}$. & 5.3 & 6.9 & 6.1 \\
\hline $\mathrm{P}-35$ & 3.77 & $8 \mathrm{hr}$. & 3.8 & 6.1 & 5.0 \\
\hline $\mathrm{P}-38$ & 2.44 & $9 \mathrm{hr}$. & 4.4 & 8.1 & 5.4 \\
\hline $\mathrm{P}-41$ & 3.01 & $2 \mathrm{~d}$ & 3.9 & 7.7 & 5.4 \\
\hline$P-42$ & 3.47 & $3 \mathrm{~d}$. & 1.6 & 7.0 & 4.5 \\
\hline$P-44$ & 2.70 & $12 \mathrm{hr}$. & 5.9 & 9.8 & 7.1 \\
\hline$P-45$ & 2.91 & $16 \mathrm{hr}$. & 4.8 & 6.2 & 5.3 \\
\hline$P-46$ & 3.38 & $6 \mathrm{hr}$. & 2.8 & 6.2 & 3.8 \\
\hline$P-47$ & 2.53 & $4 \mathrm{hr}$. & 2.3 & 4.6 & 3.3 \\
\hline$P-48$ & 2.75 & $4 \mathrm{hr}$. & 4.5 & 6.9 & 5.6 \\
\hline & & $22 \mathrm{hr}$. & 2.1 & 3.6 & 2.9 \\
\hline$P-51$ & 3.28 & $22 \mathrm{hr}$. & 2.9 & 7.9 & 5.3 \\
\hline$P-53$ & 3.46 & $8 \mathrm{hr}$. & 2.9 & 6.5 & 4.0 \\
\hline & & $2 \mathrm{~d}$ & 3.8 & 6.7 & 5.2 \\
\hline & & $6 \mathrm{~d}$. & 3.1 & 6.2 & 4.6 \\
\hline$P-54$ & 3.08 & $21 \mathrm{hr}$. & 2.8 & 5.8 & 3.9 \\
\hline & & $2 \mathrm{~d}$. & 2.9 & 8.1 & 5.2 \\
\hline$P-55$ & 3.45 & $3 \mathrm{~d}$. & 3.9 & 6.5 & 5.3 \\
\hline
\end{tabular}

hours from five infants supported the assumption that measurements made immediately after a gas collection were apparently applicable to the collection period itself. Alveolar $\mathrm{PCO}_{2}\left(\mathrm{PACO}_{2}\right)$ was considered to be in equilibrium with the "arterialized" capillary $\mathrm{P}_{\mathrm{CO}_{2}}$. $\mathrm{CO}_{2}$ production $\left(\dot{\mathrm{V}}_{\mathrm{CO}_{2}}\right)$ and $\mathrm{O}_{2}$ consumption $\left(\dot{\mathrm{V}}_{\mathrm{O}_{2}}\right)$ were calculated from the gas analyses and collection volumes using the standard respiratory equations (5). Alveolar ventilation $\left(\dot{V}_{A}\right)$ and functional dead space $\left(V_{D}\right)$ were secondarily derived from the following equations:

$$
\dot{\mathrm{V}}_{\mathrm{A}}=\dot{\mathrm{V}}_{\mathrm{CO}_{2}} \div \frac{\mathrm{PACO}_{2}}{\mathrm{P}_{\mathrm{B}}-47}
$$

where $\mathrm{PACO}_{2}$ is assumed to be equal to $\mathrm{Pa}_{\mathrm{CO}_{2}}$;

$$
\mathrm{V}_{\mathrm{D}}=\frac{\dot{\mathrm{V}}-\dot{\mathrm{V}}_{\mathrm{A}}}{\mathrm{f}}
$$

The equation for $V_{D}$ is merely an adaptation of the Bohr equation for dead space.

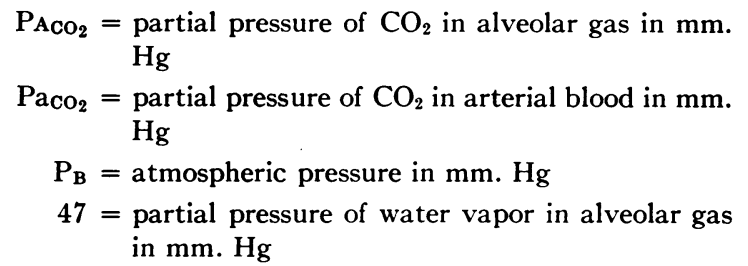

Since alveolar ventilation is related to the rate of excretion of $\mathrm{CO}_{2}$ by the lungs, it has a physiologic connotation. Consequently functional dead space, derived by subtracting tidal alveolar ventilation from tidal volume, is also a physiologic concept. In adults the space thus calculated corresponds quite closely to the "anatomic" dead space (17).

The work of respiration was estimated from a simplified formula proposed by McIlroy:

$$
\text { Work }=0.6 \mathrm{P} \dot{\mathrm{V}} \text {, in } \mathrm{Gm} . \mathrm{cm} \text {. }
$$

where $\mathrm{P}=$ the difference in $\mathrm{cm}$. of $\mathrm{H}_{2} \mathrm{O}$ between maximal and minimal pressures occurring during respiration.

This formula is based on the fact that the work of a purely elastic system would be represented by the equation $0.5 \mathrm{PV}$ (the area of a triangle) and the work of a purely viscous system, by the equation $0.79 \mathrm{P} \dot{\mathrm{V}}$ (the area of one half an ellipse). In normal adults (14) and infants (18) between 60 and 70 per cent of the work of respiration is expended against elastic resistance. Thus the constant 0.6 appears to be a reasonable figure and actually provides a good approximation of the work of normal respiration in infants when compared to more detailed methods for calculation of work (18).

\section{RESULTS}

The results of the studies are presented in Tables I, II, and III, and Figures 2 and 3 . The minute volumes, ${ }^{8}$ rates and tidal volumes listed

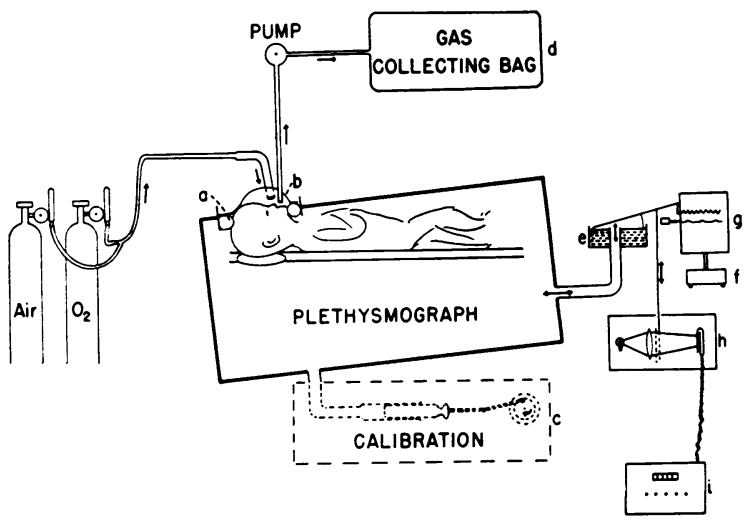

Fig. 1. Diagram of Apparatus Used for Respiratory Studies

$a$, pneumatic cuff; b, plastic face mask sealed to cuff ; c, syringe and pump used for calibration of volume recorder; d, plastic bag for collecting gas containing expired air; e, Krogh spirometer with writing pen; $f$, kymograph; g, electric timer; $h$ and $i$, photoelectric volume recorder.

${ }^{8} \mathrm{It}$ is of interest that when a body weight of $70 \mathrm{Kg}$. is substituted in the regression equations for minute volume and alveolar ventilation calculated from the infant data (Figures 2 and 3 ), the resulting volumes approximate the actual adult values (Table IV). 


\section{VENTILATION IN NEWBORN INFANTS}

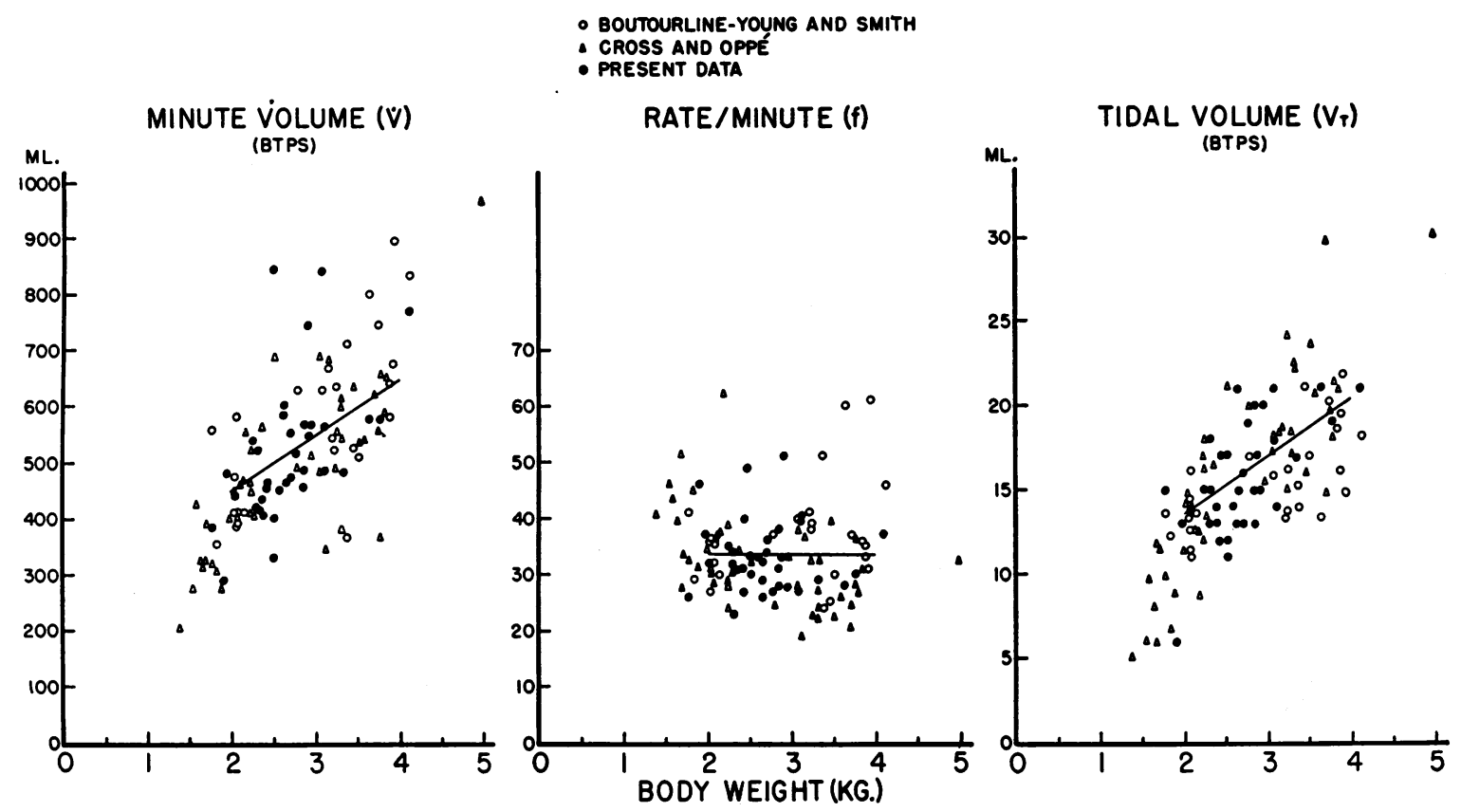

Fig. 2. Minute Volume, Rate and Tidal Volume of 107 Normal Infants

The regression lines are plotted for the weight range of 2.00 to $4.00 \mathrm{Kg}$. from the equations: $\mathrm{V}$, in $\mathrm{ml} .=251+$ $99 \cdot$ body wt. in $\mathrm{Kg}$.; $\mathrm{f}=33.6-0.11 \cdot$ body wt. in $\mathrm{Kg}$.; $\mathrm{V}_{\mathbf{T}}$, in $\mathrm{ml}$. $-6.79+3.39 \cdot$ body wt. in $\mathrm{Kg}$.

in Table I are compared on a weight basis in Figure 2 with those obtained for infants in the same age group (under seven days) by Cross and Oppé $(2,3)$ who used a similar technique, and with those reported by Boutourline-Young and Smith (1) who used a plethysmograph and a neck seal. The minute volumes from all three series appear comparable but the rates from BoutourlineYoung and Smith's report are slightly higher and tidal volumes slightly lower, discrepancies which may be related to the different methods used. In any case a significant direct relationship between both minute volume and tidal volume on the one hand and body weight on the other is obvious. In the weight range studied there is no correlation between rate and body weight.

In the 16 infants in whom additional measurements allowed calculation of alveolar ventilation ${ }^{8}$ and functional dead space (Table II and Figure 3 ), a direct relationship between these derived values and body weight is also suggested. The ratio of dead space to tidal volume ranged from 0.13 to 0.55 (average, 0.32 ), without relationship to weight or age. Oxygen consumption values for these 16 infants are also included in Table II.

Average intraesophageal pressure changes $(\triangle I E P)$ found during 32 studies of 28 normal infants (mean for group, $5 \mathrm{~cm}$. water) show no apparent relationship to weight or age over a range of 1.86 to $4.25 \mathrm{Kg}$. birth weight (Table III) and
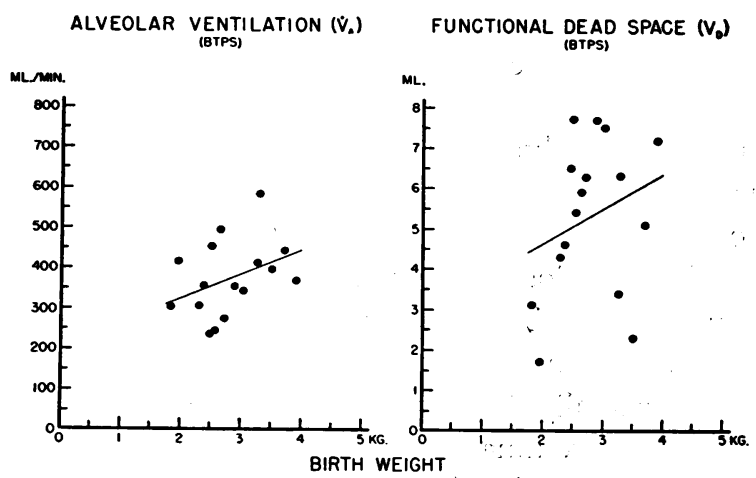

Fig. 3. Alveolar Ventilation and Functional Dead Space of 16 Normal Infants

The regression lines are plotted from the equations: $\mathrm{V}_{\Delta}$, in $\mathrm{ml} .=208+59 \cdot$ body wt. in $\mathrm{Kg}$.; $\mathrm{V}_{\mathrm{D}}$, in $\mathrm{ml} .=2.84$ $+0.88 \cdot$ body wt. in $\mathrm{Kg}$. 
are in fact, with one exception, in the range of 3 to $8 \mathrm{~cm}$. water found in adults (19).

\section{DISCUSSION}

The present study confirms earlier measurements of minute volume, rate and tidal volume in the newborn infant. By providing further information previously unavailable on related aspects of respiration, it extends the categories in which comparisons may be made with normal adult physiological data.

The following comparisons have been calculated on the basis of basal metabolism (BMR) ${ }^{9}$ because of uncertainties involved in the estimation of surface area, particularly in infants. Values for the $70 \mathrm{Kg}$. adult (BMR = 1610 Cal. per $24 \mathrm{hrs}$.) are shown in Column A of Table IV (19-22). For predicting the volume event values for a 2.5 $\mathrm{Kg}$. infant in Column $\mathrm{B}$ an average heat production of $115 \mathrm{Cal}$. per $24 \mathrm{hrs}$. has been chosen on the basis of previous reports $(23,24)$ and the $\mathrm{V}_{\mathrm{CO}_{2}}$ and $\mathrm{V}_{\mathrm{O}_{2}}$ determinations of this study. Where respiratory rate is involved in the calculations, Column $\mathrm{B}$ is divided into two sets of predicted values, one employing the adult rate of 12 , and the other the infant rate of 34 . Column $\mathrm{C}$ shows the average values for a $2.5 \mathrm{Kg}$. infant based on actual results of the present investigation.

Comparison of Columns $\mathrm{B}$ and $\mathrm{C}$ shows that the predicted and actual values for minute volume are quite similar. The predicted alveolar ventilation is slightly lower than the determined value, a fact presumably related to the lower $\mathrm{P}_{\mathrm{CO}_{2}}$ in infants compared to adults. The $\mathrm{V}_{\mathbf{T}}$ and $\mathrm{V}_{\mathbf{D}}$ predicted for the hypothetical infant breathing 12 times a minute are, as might be expected, much larger than those found. However, when the actual rate of 34 is applied to the predicted minute volume and alveolar ventilation, the resultant $V_{T}$ and $V_{D}$ are close to those found in this investigation. As can be seen from the $V_{D} / V_{T}$ ratios in Columns $\mathrm{A}$ and $\mathrm{C}$ the rapid respiration of the infant is actually accomplished with ventilatory efficiency approximately equal to that of the adult. This small functional dead space in the infant may

\footnotetext{
9 Actually, if the $2.5 \mathrm{Kg}$. infant is assumed to have a surface area of $0.17 \mathrm{M}^{2}$, adult and infant data may be compared on the basis of surface area with results similar to those in Table IV.
}

be secondary to (a) functioning respiratory epithelium in bronchi or bronchioles, (b) increased gas diffusion between alveoli and alveolar ducts or (c) relative reduction in the actual anatomic dead space. Concerning the first two possibilities, no information is available. In connection with the third, the few measurements of anatomic dead space (excluding nose and nasopharynx) in term infants range from 2.5 to $10 \mathrm{ml}$. $(25,26)$. Application of information from adults to the smaller figure would suggest a total anatomic dead space of 5.0 to $7.5 \mathrm{ml}$. for the term infant, a figure in fairly close agreement with the average physiologic dead space calculated from the present data for a slightly smaller $2.5 \mathrm{Kg}$. infant. Obviously more studies of total anatomic dead space in infants are needed for an adequate comparison between volumetric measurements and physiologic values.

An additional explanation for the rapid respiratory rate of the newborn infant may be provided by measurements of pulmonary compliance, elastic and viscous resistances and the work of respiration. Otis, Fenn, and Rahn (27) have calculated from such measurements the rate at which the "minimal work of respiration" would occur in the normal adult. Preliminary determinations and calculations in this laboratory thus far indicate that this theoretical minimum in infants may occur at the rates usually encountered. Certainly the newborn infant can increase his depth of breathing, as in many of those studied much larger tidal volumes were frequently observed in sighs or during restlessness before or after the basal periods selected for analysis. Nevertheless, the more rapid and shallow respiration may be a mechanically advantageous adaptation to physical factors peculiar to the lungs and chest of the newborn infant. These factors are at present under investigation in both the normal and abnormal infant.

The functional residual capacity $\left(\mathrm{V}_{\text {FRC }}\right)$ of a $2.5 \mathrm{Kg}$. infant calculated from measurements recently made by one of us (P. K.) (28) has been included in Table IV. The discrepancy between this figure of $70 \mathrm{ml}$. and the $193 \mathrm{ml}$. predicted from the data obtained in adult subjects requires comment. Compared on the basis of weight, the adult's lung has more than double the functional residual capacity of the infant's lung (3.7 com- 
TABLE IV

Comparison of adult and infant respiratory data

\begin{tabular}{|c|c|c|c|c|}
\hline & $\begin{array}{c}\text { Column A } \\
70 \mathrm{Kg} \text {. Adult } \\
\text { (19-22) }\end{array}$ & \multicolumn{2}{|c|}{$\begin{array}{c}\text { Column B } \\
\text { 2.5 Kg. Infant (23, 24) } \\
\text { (Predicted from adult data) } \\
\end{array}$} & $\begin{array}{c}\text { Column C† } \\
\text { 2.5 Kg. Infant } \\
\text { (Present data) } \\
\end{array}$ \\
\hline BMR (Cal./24 hrs.) & 1,610 & \multicolumn{2}{|c|}{115} & 115 \\
\hline$\dot{\mathrm{V}}_{\mathrm{O}_{2}}(\mathrm{ml} .)^{*}$ & 232 & \multicolumn{2}{|c|}{16.6} & 17 \\
\hline$\dot{\mathrm{V}}_{\mathrm{CO}_{2}}(\mathrm{ml} .)^{*}$ & 200 & \multicolumn{2}{|c|}{14.3} & 12.3 \\
\hline$\dot{\mathrm{V}}(\mathrm{ml})$. & 6,000 & \multicolumn{2}{|c|}{430} & 498 \\
\hline $\mathrm{f}$ & 12 & 12 & 34 & 34 \\
\hline $\mathrm{V}_{\mathrm{T}}$ (ml.) & 500 & 36 & 13 & 15 \\
\hline$\dot{\mathrm{V}}_{\mathrm{A}}(\mathrm{ml})$. & 4,140 & \multicolumn{2}{|c|}{296} & 355 \\
\hline $\mathrm{V}_{\mathrm{D}}(\mathrm{ml})$. & 155 & 11 & 4 & 5 \\
\hline $\mathrm{V}_{\mathrm{D}} / \mathrm{V}_{\mathrm{T}}$ & 0.31 & \multicolumn{2}{|c|}{ - } & $0.32 \S$ \\
\hline$\dot{\mathrm{V}}_{\mathrm{O}_{2}} / \dot{\mathrm{V}}_{\mathrm{A}}$ & 0.067 & \multicolumn{2}{|c|}{ 一 } & $0.062 \S$ \\
\hline$\Delta \operatorname{IEP}\left(\mathrm{cm} . \mathrm{H}_{2} \mathrm{O}\right)$ & 4.7 & \multicolumn{2}{|c|}{-} & 5.0 \\
\hline Work/min. (Gm. cm.) $\ddagger$ & 16,900 & \multirow{2}{*}{\multicolumn{2}{|c|}{$\begin{array}{r}1,210 \\
193\end{array}$}} & 1,450 \\
\hline $\mathrm{V}_{\text {FRC }}(\mathrm{ml})$. & 2,700 & & & 70 \\
\hline$\frac{V_{T}-V_{D}}{V_{F R C}}$ & 0.13 & 0.13 & 0.05 & 0.13 \\
\hline
\end{tabular}

* These volumes are STPD; all others, BTPS.

$\dagger \dot{V}$, f, and $V_{T}$ are derived from Figure 2; the $V_{F R C}$ is calculated from P. K.'s data (28); the other volume values are calculated from the data of Table II; the $\triangle$ IEP value is derived from Table III.

$\ddagger$ Work calculated from formula, 0.6 PV (18).

$\S$ These ratios represent averages from Table II.

pared to $1.4 \mathrm{ml}$. per gram), a significant difference in expansion presumably related to the obvious differences in mechanical properties of the chest wall and lungs. Nevertheless, the similarity of the infant and adult $\left(\mathrm{V}_{\mathbf{T}}-\mathrm{V}_{\mathbf{D}}\right) / \mathrm{V}_{\mathbf{F R C}}$ ratios shown in Table IV suggests that the effective ventilation of each breath bears the same relation to functional residual capacity in the infant as in the adult. This is evidence of fundamental functional similarity between infant and adult lungs in spite of certain rate, volume and mechanical differences.

The present data have shown that $\triangle \mathrm{IEP}$ and therefore, presumably, the intrapleural pressure change during respiration for the adult and for the infant is approximately the same. The actual work of respiration, as calculated from the minute volume and $\triangle$ IEP measurements corresponds closely to the predicted value in Column B. The possibility that this work may be normally performed at rates allowing minimal expenditure of energy by the infant has been considered above. In any case, if the mechanical efficiency of the respiratory muscles is estimated to be between 5 and 10 per cent, as in adults (27), the work of quiet respiration in the infant is apparently between 0.5 and 1.0 per cent of the total basal metabolism.

\section{SUMMARY AND CONCLUSIONS}

1. Measurements of respiratory minute volume, rate and tidal volume are presented for 35 normal newborn infants (birth weight, 1.82 to $4.08 \mathrm{Kg}$.) with determinations of the alveolar ventilation and functional dead space in 16 . On the basis of these studies the expected averages for a normal infant of $2.5 \mathrm{Kg}$. during the first week of life are approximately: minute volume, $498 \mathrm{ml}$.; rate, 34 ; tidal volume, $15 \mathrm{ml}$.; alveolar ventilation, $355 \mathrm{ml}$.; functional dead space, $5 \mathrm{ml}$. The average values for infants of different sizes varied directly with body weight, with the exception that rate tended to be slightly more rapid in the smaller infants.

2. Intraesophageal pressure differences during respiration were determined in 28 infants as an index of intrapleural pressure changes. The average differences between maximal and minimal pressures for individual infants showed no relationship to weight or age and, with one exception, ranged from 3 to $8 \mathrm{~cm}$. $\mathrm{H}_{2} \mathrm{O}$ pressure (mean, 5 $\mathrm{cm}$.). Work of respiration has been estimated to be approximately $1450 \mathrm{Gm}$. cm. per minute for the normal $2.5 \mathrm{Kg}$. infant.

3. Comparison, using basal metabolic rate as the common denominator, of the present data for infants with that available for normal adults indi- 
cates essential similarity of minute volume, alveolar ventilation and work of respiration. The determined tidal volume and functional dead space of the infant are smaller than predicted from the adult values. However, when the actual more rapid respiratory rate of the infant is used in the calculations, the determined and predicted values are similar. The functional residual volume in the infant appears significantly lower than that of the adult when compared on the basis of metabolism.

4. The suggestion is advanced that the comparatively rapid respiration in the infant is not only possible because of a small functional dead space but probably optimal because of elastic and viscous properties of the lung peculiar to the newborn.

\section{ACKNOWLEDGMENTS}

The authors are indebted to Doctors Jere Mead, John R. Pappenheimer and Jane Worcester for advice in the preparation of this paper. The nursing assistance of Miss E. Peterson and Miss M. Fogg is gratefully acknowledged.

\section{REFERENCES}

1. Boutourline-Young, H. J., and Smith, C. A., Respiration of full term and of premature infants. Am. J. Dis. Child., 1950, 80, 753.

2. Cross, K. W., The respiratory rate and ventilation in the newborn baby. J. Physiol., 1949, 109, 459.

3. Cross, K. W., and Oppé, T. E., The respiratory rate and volume in the premature infant. J. Physiol., 1952, 116, 168.

4. Karlberg, P., Cook, C. D., O'Brien, D., Cherry, R. B., and Smith, C. A., Studies of respiratory physiology in the newborn infant. II. Observations during and after respiratory distress. Acta paediat., 1954, 43, Suppl. 100, 397.

5. Pappenheimer, J. R., et al., Standardization of definitions and symbols in respiratory physiology. Federation Proc., 1950, 9, 602.

6. Roberts, P. W., and Widdas, W. F., Automatic integrator for volume recorders. J. Physiol., 1948, 108, 37P.

7. Scholander, P. F., Analyzer for accurate estimation of respiratory gases in one-half cubic centimeter samples. J. Biol. Chem., 1947, 167, 235.

8. Hultgren, H. N., and Hackett, A. J., Determination of the oxygen content of capillary blood in congenital heart disease. Pediatrics, 1950, 6, 93.

9. Graham, B. D., Wilson, J. L., Makepeace, U. T., Baumann, M. L., and Brown, S., Development of neonatal electrolyte homeostasis. Pediatrics, 1951, 8, 68 .
10. Cook, C. D., Cherry, R. B., and Karlberg, P., An adaptation of the capillary $\mathrm{pH}$ electrode for practical use. Pediatrics, 1955, 15, 200.

11. Rosenthal, T. B., The effect of temperature on the $\mathrm{pH}$ of blood and plasma in vitro. J. Biol. Chem., 1948, 173, 25.

12. Scholander, P. F., and Roughton, F. J. W., Microgasometric estimation of the blood gases. IV. Carbon dioxide. J. Biol. Chem., 1943, 148, 573.

13. Fry, D. L., Stead, W. W., Ebert, R. V., Lubin, R. I., and Wells, H. S., The measurement of intraesophageal pressure and its relationship to intrathoracic pressure. J. Lab. \& Clin. Med., 1952, 40, 664.

14. McIlroy, M. B., Marshall, R., and Christie, R. V., The work of breathing in normal subjects. Clin. Sc., 1954, 13, 127.

15. Mead, J., McIlroy, M. B., Selverstone, N. J., and Kriete, B. C., The measurement of intraesophageal pressure. Submitted to J. Applied Physiol.

16. Albritton, E. C., ed., Standard values in blood (Handbook of biological data, v. 1), American Institute of Biological Sciences, National Research Councii, 1951, p. 124.

17. Best, C. H., and Taylor, N. B., The Physiological Basis of Medical Practice. 5th Edition. Baltimore, Williams \& Wilkins Co., 1950, p. 364.

18. Cook, C. D., Sutherland, J. M., Segal, S., Cherry, R. B., Mead, J., McIlroy, M. B., and Smith, C. A., Studies of respiratory physiology in the newborn infant. III. Measurements of mechanics of respiration. To be published.

19. Mead, J., Unpublished data.

20. Radford, E. P., Jr., Ventilation standards for use in artificial respiration. J. Applied Physiol., In press.

21. Bartels, J., Severinghaus, J. W., Forster, R. E., Briscoe, W. A., and Bates, D. V., The respiratory dead space measured by single breath analysis of oxygen, carbon dioxide, nitrogen or helium. J. Clin. Invest., 1954, 33, 41.

22. Hickam, J. B., Blair, E., and Frayser, R., An opencircuit helium method for measuring functional residual capacity and defective intrapulmonary gas mixing. J. Clin. Invest., 1954, 33, 1277.

23. Benedict, F. G., and Talbot, F. B., Metabolism and growth from birth to puberty. Washington, Carnegie Inst., 1921, Carnegie Inst., Pub. No. 302.

24. Karlberg, P., Determinations of standard energy metabolism (basal metabolism) in normal infants. Acta paediat., 1952, 41, suppl. 89.

25. Symposium on Anoxia of the Newborn Infant, London, 1951, Oxford, Blackwell, 1953, p. 199.

26. Engel, S., Personal communication.

27. Otis, A. B., Fenn, W. O., and Rahn, H., Mechanics of breathing in man. J. Applied Physiol., 1950, 2, 592.

28. Berglund, G., and Karlberg, P., Determinations of the functional residual capacity in newborns. To be published in Acta paediat. 